\title{
Epidural blood patch in post-dural puncture headache in parturients: A case series
}

\section{Shrestha BR' ${ }^{1 D} \otimes$, Maharjan SK', Shrestha U ${ }^{3}$, Moktan SL ${ }^{4}$}

${ }^{1}$ Babu Raja Shrestha, Professor; ${ }^{2}$ Shyam Krishna Maharjan, Professor; ${ }^{3}$ Ujma Shrestha, Lecturer; ${ }^{4}$ Sushila Lama Moktan, Lecturer; Department of Anesthesiology, Kathmandu Medical College Teaching Hospital, Kathmandu, Nepal.

\begin{abstract}
This is a case series of six obstetric patients who had post-dural puncture headache, resistant to conservative treatment. The onset of post-dural headache in our series on average was on the 34th hour of the procedure. After confirmation of the diagnosis with a typical history of presentation and examination, the patients underwent pharmacological treatment. Post-dural puncture headache, in our series, not relieved by pharmacological treatment underwent epidural blood patch after persistent headache in an average of 5 days post-dural puncture. All patients receiving this therapy had a complete cure of headache at the earliest - from 45 minutes to as late as 11 hours post procedure. Epidural autologous blood instillation in an average of 10 to $11 \mathrm{ml}$ completely relieved the ailment in the primary blood patch. Epidural blood patch is still considered gold standard therapy in persistent post-dural puncture headache.
\end{abstract}

Key words: Blood patch; Epidural; Headache; Obstetric; Post-dural puncture.

\section{INTRODUCTION}

Post ost-dural puncture headache (PDPH) is best avoided by using fine pencil point spinal needles, avoidance of repeated punctures during spinal or epidural procedure. ${ }^{1}$ However, dural puncture does occur inadvertently in practice during epidurals and leaky dural weeping even in spinals. Rest, analgesics, fluids and gabapentinoids care most of the PDPH in a few days of development of headache ${ }^{2}$, but some cases might not benefit from conservative pharmacological treatment

Access this article online

Website: www.jkmc.com.np

DOI: https://doi.org/10.3126/jkmc.v9i3.36416

\section{HOW TO CITE}

Shrestha BR, Maharjan SK, Shrestha U, Moktan SL. Epidural blood patch in post-dural puncture headache in parturients: A case series. J Kathmandu Med Coll. 2020;9(3):169-172.

Address for correspondence

\section{Dr. Babu Raja Shrestha}

Professor, Department of Anesthesiology and Critical Care

Kathmandu Medical College Teaching Hospital

Kathmandu, Nepal

E-mail: barashrestha@yahoo.co.in

Copyright @ 2020 Journal of Kathmandu Medical College (JKMC)

ISSN: 2019-1785 (Print), 2091-1793 (Online)

(i) (S) This work is licensed under a Creative Commons Attribution-Non Commercial 4.0 International License. or patients prefer not to delay offered modality of treatment, like epidural blood patch (EBP) option due to intractable pain. One of the rationale behind the need of this modality in the postpartum period is, when newborn care may be severely disturbed due to the intolerable pain $^{3}$.

Autologous blood is presumed to seal the dural aperture from where the cerebrospinal fluid (CSF) leaks leading to intracranial hypotension, causing PDPH. Though effective, EBP should not be encouraged as a first option in case of PDPH. This procedure is not that commonly performed in clinical settings due to the decreasing trend of the incident because of improvised techniques and advancement of pharmacological treatment. However, reports of such therapy for PDPH are sparse and even lacking in national literature so far. It is thought that, if situations occur in future for such mode of therapy in our population, this report might offer references on patient characteristics and procedural subtle details on when to apply, how much volume of blood to apply unlike described in literature where blood volume even $20 \mathrm{ml}$ has been described ${ }^{4}$.

\section{CASE SERIES}

This is a consecutive four years case series of six parturients who had suffered PDPH after subarachnoid block (SAB) and epidural catheter placement for painless 
delivery. The epidural blood patch was administered in the operation theater of Kathmandu Medical College Teaching Hospital.

All parturients were primigravida with age ranging from 24 to 32 years (Table 1). This report shows PDPH in four patients who underwent LSCS under subarachnoid block with 25 G Quincke cutting type spinal needle (Table 1: Patients 1-4). The other two patients developed PDPH as a result of inadvertent dural puncture while having labour epidural analgesia (Table 1: Patients 5, 6).

Post operatively, these parturients complained of positional headache, moderate to severe in intensity, relieved by lying down and aggravated by sitting or standing. Some had neck pain, tinnitus, nystagmus and nausea. PDPH occurred as early as 24 hours to as late as 48 hours after the dural puncture. History and clinical assessment allowed us to diagnose the headache as PDPH. Patients were reassured and conservative treatment was started with plenty of oral fluids, nonsteroidal anti-inflammatory drugs (NSAIDs), codeine, caffeine, laxatives and abdominal binder.

With poor compliance to conservative treatment, after some days, patients were given the option of epidural blood patch (EBP). One patient completely denied to have conservative treatment and was directly taken for EBP procedure. Possible side effects were explained to them and written informed consent was taken. Complete blood count, coagulation profiles were checked prior to the EBP. Two anesthesiologists were involved in the procedure. Patients were taken to the operating room, intravenous access was secured and monitors attached to. The patients were positioned in the left lateral position and held on to the same position by a nursing staff. For EBP, the epidural space a level below the previous puncture was selected. Under full aseptic precautions, local anesthetic infiltration was done following which Tuohy epidural needle ( $18 \mathrm{G}$ ) was directed to the epidural space using loss of resistance to air technique. The 20 $\mathrm{ml}$ of autologous blood drawn aseptically by another anesthesiologist from ante-cubital fossa was handed over to the one performing the epidural puncture. The autologous blood was slowly injected into the epidural space. The end point of injection of blood was the time when the patients complained of neck pain, headache or tightness in and around the buttock or lower limbs. The volume of blood used in this report ranged from 8.5 to $13.5 \mathrm{ml}$ (Table 2).

The patients were then transferred to the post-operative ward (POW) for further monitoring and assessment. They were free of headache in the POW at different time points after the EBP, ranging from 45 minutes to 11 hours. All patients were afebrile and mobility was restored prior to their discharge from the POW.

Table 1: Patient characteristics

\begin{tabular}{|c|c|c|c|c|c|c|c|}
\hline S.N. & $\begin{array}{c}\text { Age } \\
\text { (years) }\end{array}$ & Needle (G) & Surgery & Symptoms & $\begin{array}{c}\text { Time of PDPH } \\
\text { from SAB/ } \\
\text { Epidural (hours) }\end{array}$ & $\begin{array}{l}\text { Conservative } \\
\text { treatment }\end{array}$ & $\begin{array}{l}\text { EBP given } \\
\text { on }\end{array}$ \\
\hline 1. & 28 & $\begin{array}{c}25 \mathrm{G} \\
\text { Quincke }\end{array}$ & $\begin{array}{l}\text { Lower } \\
\text { segment } \\
\text { caesarean } \\
\text { section (LSCS) }\end{array}$ & $\begin{array}{l}\text { Headache(positional) } \\
\text { Blurred vision }\end{array}$ & 36 & $\begin{array}{l}\text { Bed rest, fluids, } \\
\text { paracetamol, Codeine, } \\
\text { Cremaffin, Abdominal } \\
\text { binder, Caffeine drink }\end{array}$ & $5^{\text {th }}$ day \\
\hline 2. & 26 & $\begin{array}{c}25 \mathrm{G} \\
\text { Quincke }\end{array}$ & LSCS & Headache(positional) & 48 & $\begin{array}{l}\text { Bed rest, fluids, } \\
\text { paracetamol and } \\
\text { caffeine(Dolopar), } \\
\text { Cremaffin, Abdominal } \\
\text { binder, Caffeine drink }\end{array}$ & $6^{\text {th }}$ day \\
\hline 3. & 32 & $\begin{array}{c}25 \mathrm{G} \\
\text { Quincke }\end{array}$ & LSCS & $\begin{array}{l}\text { Neck pain } \\
\text { Headache }\end{array}$ & 24 & $\begin{array}{l}\text { Bed rest, fluids, } \\
\text { Dolopar, Codeine, } \\
\text { Cremaffin, Abdominal } \\
\text { binder, Caffeine drink }\end{array}$ & $5^{\text {th }}$ day \\
\hline 4. & 24 & $\begin{array}{c}25 \mathrm{G} \\
\text { Quincke }\end{array}$ & LSCS & $\begin{array}{l}\text { Headache(positional) } \\
\text { Nystagmus } \\
\text { Nausea }\end{array}$ & 48 & $\begin{array}{l}\text { Bed rest, fluids, } \\
\text { paracetamol, Codeine, } \\
\text { Cremaffin, Abdominal } \\
\text { binder, Caffeine drink }\end{array}$ & $5^{\text {th }}$ day \\
\hline
\end{tabular}


Table 1 cont ...

\begin{tabular}{|c|c|c|c|c|c|c|c|}
\hline 5. & 25 & 18 G Tuohy & LSCS & Headache(positional) & 24 & $\begin{array}{l}\text { Bed rest, fluids, } \\
\text { Dolopar, Cremaffin, } \\
\text { Abdominal binder, } \\
\text { Caffeine drink }\end{array}$ & $\begin{array}{l}3^{\text {rd }} \text { day } \\
\text { (denial of } \\
\text { conservative } \\
\text { treatment by } \\
\text { patient) }\end{array}$ \\
\hline 6. & 30 & 18 G Tuohy & LSCS & $\begin{array}{l}\text { Headache (positional) } \\
\text { Tinnitus } \\
\text { Neck pain }\end{array}$ & 24 & $\begin{array}{l}\text { Bed rest, fluids, } \\
\text { Dolopar, Cremaffin, } \\
\text { Abdominal binder, } \\
\text { Caffeine drink }\end{array}$ & $5^{\text {th }}$ day \\
\hline
\end{tabular}

Table 2: Epidural blood patch volume used and symptom relief time

\begin{tabular}{ccc|}
\hline S.No. & Epidural blood volume $(\mathbf{m l})$ & Headache relieved in \\
\hline 1 & 8.5 & 6 hours \\
\hline 2 & 11 & 45 minutes \\
\hline 3 & 13.5 & 4.5 hours \\
\hline 4 & 12.5 & 11 hours \\
\hline 5 & 10.3 & 6 hours \\
\hline 6 & 9 & 8 hours \\
\hline
\end{tabular}

\section{DISCUSSION}

PDPH is a possible complication of neuraxial anaesthesia; cerebrospinal fluid loss and decreased circulating CSF volume has been claimed to be the cause of PDPH. The incidence of PDPH is $<1 \%$ following subarachnoid block performed with a $25 \mathrm{G}$ spinal needle. ${ }^{5}$ Inadvertent dural puncture is $0.18 \%-6 \%$ and about 50 to $70 \%$ of them might develop PDPH with a 16-18 G epidural needle ${ }^{6}$, ${ }^{7}$. Usually patients are cured with pharmacological treatment comprising of a strict bed rest, NSAIDs, ancillary treatment with laxatives in case of constipation to avoid straining during defecation and to negate inhibitory action of opioids used in bowel movement, caffeine, gabapentinoids, abdominal binders and plenty of fluids. When conservative therapy is not effective or takes a long time to cure limiting daily performances of patients, epidural blood patch should be given as an alternative option. The EBP rate in $\mathrm{PDPH}$ is $25.7 \%$ and the need of second EBP is $5.3 \% .^{5}$

It was Groomely who first described the treatment of PDPH with EBP in $1960 .{ }^{8}$ Continuous or intermittent loss of CSF from the dural hole leads to cerebral vasodilatation and dural traction. Autologous blood (fibrin) deposited epidurally seals the dural hole and prevents CSF leak from subarachnoid space. EBP is usually performed 24 hours after PDPH for improved outcome (around 90\%). Blood patch performed within 24 hours of dural puncture shows a sub-optimal outcome or shows unsatisfactory response $e^{9,10}$.
In our case series, the earliest EBP was given on the third day. Most of the other cases were done on the fifth day of diagnosis, after they did not tolerate conservative treatment well. There is a report of PDPH being selflimiting (in 1-2 weeks) when the puncture site heals by natural fibrosis. However, the exact period varies in different cases due to multiple confounding factors: needle size, needle type (cutting vs pencil point), type of surgery (obstetrics vs non-obstetrics), gender, body weight etc. These factors even contribute to the incidence and severity of headache ${ }^{11}$. Our patients who benefitted from EBP received a minimum of $8.5 \mathrm{ml}$ to a maximum of $13.5 \mathrm{ml}$. The end point of injection of blood was the time when patients complained of any discomforts like neck pain, headache, heaviness on back, buttock and lower limbs as the blood was being injected. The final volume of blood used was between 13 to $14 \mathrm{ml}$ unless the patient complained of above mentioned symptoms. It is very important to inject the blood very slowly in 30 to $60 \mathrm{sec}$ to minimize possible unwelcomed neurogenic reflexes. ${ }^{5}$ Important to note, literature is lacking to clarify the association between success rate of EBP and volume of blood administered. The volume of autologous blood used for EBP varies from 10-20 ml. The exact prescription of blood volume is not found elsewhere ${ }^{12}$.

There are certain instructions to the patients after EBP that might result in a more complete resolution of symptoms, e.g.; lying on lateral position, avoidance of lifting weight, straining, Valsalva maneuver, and prohibiting air travel for first 24 to $48 \mathrm{hrs}$ to prevent blood patch dislocation ${ }^{13}$. 
Relief of headache occurred as early as $45 \mathrm{~min}$ in one case, whereas it took four to six to 11 hours for headache to be relieved in other cases. There are reports that describe failure of first EBP (success rate> 85\%) with need of second one with success rate of more than $97 \% .{ }^{14}$ There has been a favorable trend of decreasing incidence of PDPH with the advent of newer fine pencil point spinal needles, improvisation in skills with start of postgraduate program in anesthesiology in our institution. The sporadic incidence of PDPH now-a-days gets better with conservative multifaceted treatments and the need of

\section{REFERENCES}

1. Serpell MG, Haldane GJ, Jamieson DR. Prevention of headache after lumbar puncture: Questionnaire survey of neurologists and neurosurgeons in United Kingdom. Br Med J. 1998 Jun;316:1709-10. [PubMed | Full Text | DOI]

2. Wagner Y, Storr F, Cope S. Gabapentin in the treatment of post-dural puncture headache: A case series. Anaesth Intensive Care. 2012 Jul;40:714-8. [PubMed | FullText |DOI]

3. Vilming ST, Kloster R, Sandvik L. When should an epidural blood patch be performed in post-lumbar puncture headache? A theoretical approach based on a cohort of 79 patients. Cephalalgia. 2005 Jul;25(7):523-7. [PubMed |DOI]

4. Chen LK, Huang $\mathrm{CH}$, Jean $\mathrm{WH}$, et al. Effective epidural blood patch volumes for postdural puncture headache in Taiwanese women. J Formos Med Assoc 2007 Feb;106:134-40. [PubMed | Full Text| DOI]

5. Tubben RE, Jain S, Murphy PB. Epidural blood patch. StatPearls [Internet]. ; 2020 Jan. [cited 2020 Jul]. [ PubMed | Full Text]

6. Banks S, Paech M, Gurrin L. An audit of epidural blood patch after accidental dural puncture with a Tuohy needle in obstetric patients. International Journal of Obstetric Anesthesia. Elsevier BV; 2001 Jul;10(3):172-6. [PubMed | DOI]

7. Heesen $M$, Klöhr S, Rossaint R, Van De Velde $M$, Straube S. Can the incidence of accidental dural puncture in laboring women be reduced? A systematic review and meta-analysis. Minerva Anestesiol. 2013 Oct;79(10):1187-97. [PubMed | Full Text]
EBP has become a mere historical significance. However, acquisition of EBP practice might hold its value some time in unknown days later.

\section{CONCLUSION}

Epidural blood patch is a useful procedure in post-dural puncture headache when conservative therapy fails to relieve the symptoms.

\section{Conflict of interest: None \\ Source(s) of support: None}

8. Szeinfeld $M$, Ihmeidan $\mathbf{I H}$, Moser MM,Machado $R$, KloseKJ,Serafini AN. Epidural blood patch:Evaluation of the volume and spread of blood injected into the epidural space. Anesthesiology,1986;64:820-2. [PubMed | Full Text|DOI]

9. Kokki $M$, Sjövall $S$, Keinänen $M$, Kokki $H$. The influence of timing on the effectiveness of epidural blood patches in parturients. International Journal of Obstetric Anesthesia. Elsevier BV; 2013 Nov;22(4):303-9. [PubMed | DOI]

10. Loseser EA, Hill GE, Bennett GM, Sedernerg JH. Time vs. Success Rate for Epidural Blood Patch. Anesthesiology . Ovid Technologies (Wolters Kluwer Health); 1978 Aug 1;49(2):147-8. [PubMed | Full Text |DOI]

11. Gaiser RR. Postdural puncture headache. Current Opinion in Anaesthesiology]. Ovid Technologies (Wolters Kluwer Health). 2013 Jun;26(3):296-303. [ PubMed | DOI]

12. Paech MJ, Doherty DA, Christmas T, Wong CA. The volume of blood for epidural blood patch in obstetrics: A randomized, blinded, clinical trial. Anesthesia \& Analgesia. 2011 Jul;113(1):126-33. [PubMed | FullText | DOI]

13. Stride PC, Cooper GM. Dural taps revisited: A 20 year survey from Birmingham Maternity Hospital. Anesthesia 1993;48:247-55. [PubMed |DOI]

14. Smedstad KG. Dealing with post-dural puncture headache - is it different in obstetrics? Canadian Journal of Anaesthesia. Springer Science and Business Media LLC. 1998 Jan; 45(1):6-9. [PubMed | Full Text | DOI] 